Claremont Colleges

Scholarship@ Claremont

Pitzer Faculty Publications and Research

Pitzer Faculty Scholarship

$11-14-2012$

\title{
Sex Differences in Normal Fetuses and Infants: A Commentary
}

David S. Moore

Pitzer College

\section{Recommended Citation}

Moore, D. S. (2012), Sex Differences in Normal Fetuses and Infants: A Commentary. Child Development Perspectives, 6: 414-416. doi: $10.1111 /$ j.1750-8606.2012.00258.x Post-print.

This Article - postprint is brought to you for free and open access by the Pitzer Faculty Scholarship at Scholarship @ Claremont. It has been accepted for inclusion in Pitzer Faculty Publications and Research by an authorized administrator of Scholarship @ Claremont. For more information, please contact scholarship@cuc.claremont.edu. 
Running head: SEX DIFFERENCES

The content of this open-access post-print article is the same as that contained in the published article with the following reference:

Moore, D. S. (2012). Sex differences in normal fetuses and infants: A commentary. Child Development Perspectives, 6, $414-416$.

Sex differences in normal fetuses and infants: A commentary

David S. Moore

Pitzer College \& Claremont Graduate University

March 18, 2012 


\begin{abstract}
Sex differences in infants warrant attention, not because they clarify the extent to which such differences reflect Nature or Nurture, but because studying them is likely to illuminate the origins of sex differences later in life and thereby yield manipulations that could influence the development of important competences. It is not yet clear how male and female infants come to differ. Testosterone is influential, but because of the complexity of the developmental systems in which it operates, its effects are not straightforward: testosterone does different things in different contexts. We should not expect simple explanations invoking hormone exposure to satisfactorily answer our questions about the origins of sex differences, but standardizing protocols to allow meaningful meta-analyses would help bring coherence to the research literature in this domain.
\end{abstract}


Sex differences in normal fetuses and infants: A commentary

Interest in sex differences in infancy is driven partly by the desire to learn how males and females differ before socialization. However, socialization begins at birth because adults have different perceptions of and expectations for male and female babies (Stern \& Karraker, 1989). Because people treat boys and girls differently, it is impossible to tease apart biological and sociocultural contributions to sex differences appearing after birth.

Nonetheless, the findings that newborn girls are "significantly more cuddly than boys" (Benenson, Philippoussis, \& Leeb, 1999, p. 338) and that "female neonates expressed more facial features of pain" (Guinsburg et al., 2000, p. 130) cannot reflect social influences. (In some other studies of neonatal sex differences [e.g., Nagy, Kompagne, Orvos, \& Pal, 2007], coders were not blind to the sex of observed infants; results from such studies are uninterpretable.) Still, neonates' characteristics always reflect the influence of nonsocial environmental factors. Fetuses develop in uterine environments that vary with fetal sex, so newborns' characteristics likely reflect these environments. In fact, males and females develop in amniotic fluid that differs, at some gestational ages, in concentrations of molecules involved in intercellular communication and embryogenesis, namely, hormones and possibly some cytokines. As Constantinescu and Hines (2012) report, male and female fetuses are exposed to differing concentrations of testosterone, and although the findings on other hormones and cytokines have not yet been as conclusively established, various laboratories have found male versus female prenatal environments to differ in concentrations of angiogenin (Poggi, Spong, Ghidini, \& Ossandon, 2004), interleukin 5 (Chow et al., 2008), and leptin (Bugatto et al., 2010; Helland, Reseland, Saugstad, \& Drevon, 1998). Because leptin, angiogenin, and testosterone influence birth weight, vascularization, and neural characteristics, respectively, they could influence many phenotypic 
differences between newborn boys and girls, thereby influencing infants' postnatal social experiences. Thus, even behaviors in babies just several hours old are not more purely "biological" than are older children's behaviors. Currently, we are just beginning to understand what makes male and female neonates differ, but it is clear that sex-typical characteristics at birth emerge from complex processes involving interactions between differing male and female genomes and uterine environments.

What should concern us is not whether sex differences are caused more by Nature or Nurture, but rather how we can influence the development of specific competences. Consider, for example, that there are gender differences in spatial skills (Halpern, 2011) that are influenced by experience (Hoffman, Gneezy, \& List, 2011) and that are essential for success in engineering and technology professions. Women are underrepresented in these fields (Hill, Corbett, \& St. Rose, 2010), and their diminished presence in such lucrative occupations is one reason women earn less than men on average (American Association of University Women, 2011; Ryle, 2011). Understanding the origins of spatial skills in a way that allows us to influence their development could ultimately enable women's movement into these profitable professions. Parents routinely construct children's environments to provide tools that help them thrive (for example, literacy); thoughtful parents would also likely use knowledge about how to help boys and girls develop skills traditionally seen as strengths of the other gender if those skills would increase their children's fulfillment.

Studying sex differences in infants is worthwhile because "infants [might] have sexlinked dispositions that represent 'seeds' of later behavior" (Alexander \& Wilcox, 2012, p. 400). If so, it might be most effective to influence sex differences in adults via manipulations implemented in infancy. By identifying early-appearing sex differences that might be 
components of later-emerging sex differences, Alexander and Wilcox (2012) have provided a valuable service.

In contrast to Alexander and Wilcox's (2012) focus on sex differences in postnatal behavior, Constantinescu and Hines (2012) focus on prenatal testosterone's contributions to such differences; both complementary approaches will ultimately yield increased understanding. However, both articles imply that we still know surprisingly little about this topic. Constantinescu and Hines's review suggests that the relationship between prenatal testosterone and postnatal behavior in normal children is far from established, but their review does not consider studies of atypical populations, such as offspring of females prescribed hormones during pregnancy or girls diagnosed with congenital adrenal hyperplasia. After a broader review, Alexander and Wilcox conclude that the evidence "supports the masculinizing effects of prenatal testosterone on social and cognitive behavior" (p. 400), and this is the general consensus (e.g., Hines, 2011). Studies of individuals developing in normal hormone environments, though, have yet to generate agreed-on understandings of the effects of prenatal sex hormone exposure.

One theme in both articles is the lack of replication of many studies in this domain. Additionally, some researchers find trends in the opposite direction of what others predict (Geangu, Benga, Stahl, \& Striano, 2010), some find testosterone accounting for behavioral differences in only one sex or having opposite effects on males and females (Grimshaw, Sitarenios, \& Finegan, 1995), and some find behavioral sex differences unrelated to prenatal testosterone exposure in either sex (Knickmeyer et al., 2005). No unambiguous pattern emerges from the studies that Constantinescu and Hines (2012) review; what is clear is that some sex differences appear to be independent of testosterone concentrations in amniotic fluid.

Why have these studies generated inconsistent results? All but two examined amniotic 
testosterone, but Rodeck, Gill, Rosenberg, and Collins (1985) - the only study to examine the correlation between amniotic and fetal blood testosterone-reported no such correlation, so it should be unsurprising that amniotic testosterone is not related to postnatal behavior in an easily detectable way. Constantinescu and Hines (2012) discuss two studies that examined testosterone in maternal serum during gestation, and although the one study that looked (Gitau, Adams, Fisk, \& Glover, 2005) found that this variable is correlated with fetal serum testosterone, it is impossible to draw firm conclusions from such limited data.

There are good reasons not to expect measures of testosterone in any fluid — amniotic, maternal serum, or even fetal blood— to be clearly associated with postnatal behavior. Testosterone's functionality is affected by several factors operating within developing personenvironment systems, among which are the presence and concentration of testosterone receptors in the brain (without which testosterone is ineffectual) and of sex hormone binding globulin (which binds free testosterone, thereby reducing its bioavailability). Because testosterone can affect the brain only when it interacts (and does not interact) with specific molecules, its effects on behavior are not direct. Moreover, once testosterone reaches and binds with receptors, it has numerous effects, including altering cell numbers in specific brain structures, inducing outgrowth of axons and dendrites, supporting synaptogenesis, regulating cell death, and affecting axonal guidance and therefore neural connectivity (Hines, 2011; Simerly, 2002). Thus, testosterone does many things (as expected, given that it is evolutionarily ancient; Guerriero, 2009), and through its interactions with androgen receptors and a variety of molecular coregulators, it is able to produce different effects in different cell types (Li \& Al-Azzawi, 2009). Consequently, we ought not expect its effects on behavior to be straightforward; instead, we should understand testosterone to be a relatively nonspecific agent capable of contributing to 
several effects in context-specific ways.

This conclusion is supported by the finding that testosterone can correlate with a competence within a sex, even if there is no sex difference in the competence (e.g., Finegan, Niccols, \& Sitarenios, 1992; Grimshaw, Bryden, \& Finegan, 1995; Jacklin, Wilcox, \& Maccoby, 1988). When testosterone accounts for variation like this, it seems to have a direct causal role in the development of the competence. But where correlations exist within female populations (for example) even in the absence of sex differences in a competence, testosterone must not cause the competence in a context-independent way; otherwise, it would affect males, too, and a sex difference would be detectable because males are exposed to more testosterone. Of course, the findings in all three studies cited here could be spurious, but if they reflect real phenomena, we could understand them by acknowledging that testosterone is operating in different contexts in male and female bodies. But this would mean that references to testosterone alone will never yield satisfactory answers to questions about how male-typical or female-typical behaviors develop in either sex.

Constantinescu and Hines (2012) offer valuable suggestions for the future, including using large samples, studying the contents of maternal blood as well as amniotic fluid, controlling for variables like gestational age and time of day when samples are taken, and reporting null results. The latter will be critical for correctly interpreting meta-analyses of data in this domain. Such meta-analyses will be indispensable; without them, it will remain hard to contend with inconsistent results. Currently, meta-analyses might be premature, because existing studies are few, they have used varying behavioral outcome measures, and they have measured testosterone in different ways at different times (in gestation and diurnally). Our understanding of the development of sex differences will improve once researchers implement standardized 
protocols that allow comparisons of results across studies. 


\section{References}

Alexander, G. M., \& Wilcox, T. (2012). Sex differences in early infancy. Child Development Perspectives, 6, 400-406.

American Association of University Women. (2011). The simple truth about the gender pay gap. Washington, DC: Author.

Benenson, J. F., Philippoussis, M., \& Leeb, R. (1999). Sex differences in neonates' cuddliness. The Journal of Genetic Psychology, 160, 332-342.

Bugatto, F., Fernández-Deudero, Á., Bailén, Á., Fernández-Macías, R., Hervías-Vivancos, B., \& Bartha, J. L. (2010). Second-trimester amniotic fluid proinflammatory cytokine levels in normal and overweight women. Obstetrics \& Gynecology, 115, 127-133.

Chow, S. S. W., Craig, M. E., Jones, C. A., Hall, B., Catteau, J., Lloyd, A. R., \& Rawlinson, W. D. (2008). Differences in amniotic fluid and maternal serum cytokine levels in early midtrimester women without evidence of infection. Cytokine, 44, 78-84.

Constantinescu, M., \& Hines, M. (2012). Relating prenatal testosterone exposure to postnatal behavior in typically developing children: Methods and findings. Child Development Perspectives, 6, 407-413.

Finegan, J. K., Niccols, G. A., \& Sitarenios, G. (1992). Relations between prenatal testosterone levels and cognitive abilities at 4 years. Developmental Psychology, 28, 1075-1089.

Geangu, E., Benga, O., Stahl, D., \& Striano, T. (2010). Contagious crying beyond the first days of life. Infant Behavior \& Development, 33, 279-288.

Gitau, R., Adams, D., Fisk, N. M., \& Glover, V. (2005). Fetal plasma testosterone correlates positively with cortisol. Archives of Disease in Childhood. Fetal and Neonatal Edition, 90, F166-F169. 
Grimshaw, G. M., Bryden, M. P., \& Finegan, J. K. (1995). Relations between prenatal testosterone and cerebral lateralization in children. Neuropsychology, 9, 68-79.

Grimshaw, G. M., Sitarenios, G., \& Finegan, J. K. (1995). Mental rotation at 7 years: Relations with prenatal testosterone levels and spatial play experiences. Brain and Cognition, 29, $85-100$.

Guerriero, G. (2009). Vertebrate sex steroid receptors: Evolution, ligands, and neurodistribution. Annals of the New York Academy of Sciences, 1163, 154-168.

Guinsburg, R., Araujo Peres, C., Almeida, M., Cassia Xavier Balda, R., Cassia Berenguel, R., Tonelotto, J., \& Kopelman, B. I. (2000). Differences in pain expression between male and female newborn infants. Pain, 85, 127-133.

Halpern, D. F. (2011). Sex differences in cognitive abilities (4th ed.). London: Psychology Press.

Helland, I. B., Reseland, J. E., Saugstad, O. D., \& Drevon, C. A. (1998). Leptin levels in pregnant women and newborn infants: Gender differences and reduction during the neonatal period. Pediatrics, 101 , e12.

Hill, C., Corbett, C., \& St. Rose, A. (2010). Why so few? Women in science, technology, engineering, and mathematics. Washington, DC: American Association of University Women.

Hines, M. (2011). Gender development and the human brain. Annual Review of Neuroscience, $34,69-88$.

Hoffman, M., Gneezy, U., \& List, J. A. (2011). Nurture affects gender differences in spatial abilities. Proceedings of the National Academy of Sciences of the USA, 108, 1478614788. 
Jacklin, C. N., Wilcox, K. T., \& Maccoby, E. E. (1988). Neonatal sex-steroid hormones and cognitive abilities at six years. Developmental Psychobiology, 21, 567-574.

Knickmeyer, R.C., Wheelwright, S., Taylor, K., Raggatt, P., Hackett, G., \& Baron-Cohen, S. (2005). Gender-typed play and amniotic testosterone. Developmental Psychology, 41, $517-528$

Li, J., \& Al-Azzawi, F. (2009). Mechanism of androgen receptor action. Maturitas, 63, 142-148.

Nagy, E., Kompagne, H., Orvos, H., \& Pal, A. (2007). Gender-related differences in neonatal imitation. Infant and Child Development, 16, 267-276.

Poggi, S. H., Spong, C. Y., Ghidini, A., \& Ossandon, M. (2004). Gender differences in amniotic fluid cytokine levels. The Journal of Maternal-Fetal and Neonatal Medicine, 15, 367371.

Rodeck, C. H., Gill, D., Rosenberg, D. A. \& Collins, W. P. (1985). Testosterone levels in midtrimester maternal and fetal plasma and amniotic fluid. Prenatal Diagnosis, 5, 175181.

Ryle, R. (2011). Questioning gender: A sociological exploration. Thousand Oaks, CA: Sage.

Simerly, R. B. (2002). Wired for reproduction: Organization and development of sexually dimorphic circuits in the mammalian forebrain. Annual Review of Neuroscience, 25, 507536.

Stern, M., \& Karraker, K. H. (1989). Sex stereotyping of infants: A review of gender labeling studies. Sex Roles, 20, 501-522. 


\section{Author Note}

David S. Moore, Pitzer College \& Claremont Graduate University.

This article was written with the support of the Research and Awards Committees of Pitzer College.

I am grateful for the support and help provided in connection with this project by Melissa Hines and Dawn Moore.

Correspondence concerning this article should be addressed to David Moore, at Pitzer College, Claremont, CA 91711. 